Огляди літератури, оригінальні дослідження, погляд на проблему, ювілеї

УДК 616.314.17-008.1-036.11-06:616.441-008.64-06:612.017.1] - 092.9

DOI 10.11603/1811-2471.2019.v0.i1.10050

\title{
ОСОБЛИВОСТІ НЕСПЕЦИФІЧНОӦ І СПЕЦИФІЧНОЇ ЛАНОК ІМУННОГО ЗАХИСТУ У ЩУРІВ З ГОСТРИМ ПАРОДОНТИТОМ НА ТЛІ ГІПОТИРЕОЗУ
}

\author{
ДВНЗ «Тернопільський державний медичний університет імені І. Я. Горбачевського моз України»
}

РЕзюМЕ. Для вивчення впливу експериментального гіпотиреозу на стан неспецифічної і специфічної ланок імунного захисту у щурів з гострою травмою м' яких тканин ясен було проведено НСТ-тест, визначено показники клітинної ланки імунної системи (CD4, CD8), а також досліджено вміст lgG, IgM i lgA у сироватці крові на аналізаторі Stat FAX (USA).

Мета - вивчити особливості неспецифічної і специфічної ланок імунного захисту у щурів з гострим пародонтитом на тлі гіпотиреозу.

Матеріал і методи. Гіпотиреоз у щурів викликали уведенням мерказолілу в дозі 25 мг/кг протягом 21 доби. Контроль здійснювали за рівнями тироксину, трийодтироніну і тиреотропного гормону, а також за масою тварин і їх руховою активністю. До групи порівняння входили тварини, яким мерказоліл не вводили. Вплив гіпотиреозу на перебіг запального процесу при пародонтиті вивчали на моделі запалення, викликаного гострою травмою м'яких тканин ясен. Тваринам під тіопенталовим наркозом (30 мг/кг) з губної сторони до тканин пародонта нижнього різця підводили робочу головку ультразвукового генератора - випромінювач від ультразвукового скейлера ART (Великобританія), і здійснювали однократний направлений вплив коливаннями ультразвукової частоти при наступних параметрах впливу: частота коливань 50 кГц, потужність випромінювання 1,2 Вт·см ${ }^{2}$ при експозиції впливу 60 с. Операцію проводили на 14 добу після першого введення мерказолілу. Через 1 і 8 діб після операції щурів декапітували під тіопенталовим наркозом (50 мг/кг). Групами порівняння були тварини з експериментальним гіпотиреозом і щури з гострою механічною травмою м'яких тканин ясен. Контролем служив матеріал від інтактних тварин.

Результати. Запалення у щурів з гострою травмою ясен на тлі гіпотиреозу призводило до збільшення вмісту активних нейтрофілів у периферійній крові, зниження CD-4-лімфоцитів, порушення співвідношення основних субпопуляцій лімфоцитів (CD-4 і CD-8), що супроводжується достовірним зниженням імунорегуляторного індексу, пригніченням секреції IgG, IgM i IgA на системному рівні.

Висновки. В еутиреоїдних щурів спостерігали нормальний перебіг запального процесу із переважанням зростання Т-хелперів над рівнем цитотоксичних Т-лімфоцитів і, відповідно, зростанням імунорегуляторного індексу. Виявлена недостатність клітинної ланки імунної відповіді відображає посилення взаємного негативного впливу запального процесу в пародонті і системних порушень імунного захисту за умов супутнього дефіциту гормонів щитоподібної залози. За умови модельованого гострого пародонтиту на тлі гіпотиреозу вже на 1 добу відмічалося пригнічення гуморальної ланки імунної системи, яке характеризувалось достовірним зниженням імуноглобулінів усіх класів.

КлючОВІ СлОВА: запалення пародонта; гіпотиреоз; неспецифічна і специфічна ланки імунного захисту.

Вступ. Останнім часом порушення функціонального стану щитоподібної залози набули значного поширення. Дані літератури свідчать про часте ураження тканин організму, в тому числі пародонта, при дисфункції щитоподібної залози, а ступінь і вираженість патологічного процесу залежать від тяжкості та тривалості гіпотиреозу [1, 4, 7]. Недостатньо вивчена роль гормонів щитоподібної залози в реалізації функціональної активності клітин імунної системи визначила актуальність вивчення особливостей перебігу запалення на фоні гіпотиреозу $[6,9,11]$. Запальний процес, що триває на тлі гіпотиреозу, як системна відповідь організму, має певні особливості формування і перебігу. Ці зміни зумовлені зниженням функціональної активності клітин, що беруть участь у формуванні запальної відповіді [2, 3]. 3 метою вивчення стану неспецифічної і специфічної ланок імунного захисту ми використали модель запаль- ного процесу пародонта на тлі експериментального гіпотиреозу.

Мета - дослідження впливу зниженої продукції тиреоїдних гормонів на стан неспецифічної і специфічної ланок імунного захисту в організмі тварин з гострим експериментальним пародонтитом.

Матеріал і методи дослідження. Дослідження проводили на білих безпородних щурах-самцях масою тіла 180-200 г, отриманих з віварію ТДМУ, відповідно до вимог «Правил проведення робіт з використанням експериментальних тварин» $[5,8]$. Тварини перебували на повноцінному раціоні віварію з вільним доступом до води. Гіпотиреоз моделювали щоденним введенням рег os за допомогою спеціального зонда фармакопейного тиреостатика мерказолілу («Акрихин», Росія) у дозі 25 мг/кг протягом 21 доби [10]. Контроль здійснювали за рівнями тироксину, трийодтироніну і 
Огляди літератури, оригінальні дослідження, погляд на проблему, ювілеї

тиреотропного гормону, а також за масою тварин і їх руховою активністю. До групи порівняння увійшли тварини, яким мерказоліл не вводили. Вплив гіпотиреозу на перебіг запального процесу при пародонтиті вивчали на моделі запалення, викликаного гострою травмою м'яких тканин ясен [8]. Тваринам під тіопенталовим наркозом (30 мг/кг) 3 губної сторони до тканин пародонта нижнього різця підводили робочу головку ультразвукового генератора - випромінювач від ультразвукового скейлера ART (Великобританія), і здійснювали однократний направлений вплив коливаннями ультразвукової частоти при наступних параметрах впливу: частота коливань 50 кГц, потужність випромінювання 1,2 Вт·см² при експозиції впливу 60 с. Операцію проводили на 14 добу після першого введення мерказолілу. Через 1 і 8 діб після операції щурів декапітували під тіопенталовим наркозом (50 мг/кг). Групами порівняння служили тварини з експериментальним гіпотиреозом і щури 3 гострою механічною травмою м'яких тканин ясен. Контролем служив матеріал від інтактних тварин.

Показники клітинного імунітету визначали за методом M. Bunders, який ґрунтується на взаємодії моноклональних антитіл (МКАт), мічених флуоресцентою міткою, з поверхневими антигенами лімфоцитів [13]. У кожну пробірку вносили 20 мкл антитіл (CD4/CD8) і ЕДТА, не торкаючись наконечником стінок пробірки. Зразки перемішували на вортексі та інкубували в темному місці 15-30 хв при кімнатній температурі. Рекомендована кількість лейкоцитів - 3,5-9,4 Г/л. Для лізису еритроцитів у кожну пробірку вносили по 500 мкл лізуючого розчину, струшували на вортексі й інкубували 1015 хв при кімнатній температурі. Додавали до пробірок по 500 мкл буферного розчину. Зразки аналізували на проточному цитофлуориметрі Epics-XL виробництва «Beckman Coulter» (США) [14].

Вміст імуноглобулінів сироватки крові вивчали методом твердофазового імуноферментного аналізу 3 використанням наборів реагентів «eBioscience, Inc» (США) згідно з інструкціями фірми-виробника на аналізаторі STATFAX. Кількість імуноглобулінів виражали у грамах на літр (г/л).

Результати й обговорення. Аналіз параметрів імунної системи у тварин з гострим пародонтитом на тлі індукованого гіпотиреозу здійснювали за допомогою порівняльного дослідження імунологічних показників здорових тварин, тварин з гіпотиреозом, тварин з гострим пародонтитом без гіпотиреозу і тварин, яким пародонтит моделювали на тлі гіпотиреозу. Для оцінки стану імунної системи у тварин цих груп досліджували імунологічні показники, які відображають функціональну активність фагоцитарної, клітинної і гуморальної ланок, а також цитокіновий статус.

3 метою аналізу функціональної активності фагоцитарної ланки ми проводили тест з нітросинім тетразолієм. Порівняльне дослідження функціональної активності нейтрофілів (табл. 1) не виявило суттєвих відмінностей у показниках сНСТтесту у щурів з експериментальним гіпотиреозом і інтактних тварин, однак при стимуляції пірогеналом кількість диформазан-позитивних нейтрофілів підвищилась меншою мірою у щурів зі зниженою продукцією тиреоїдних гормонів.

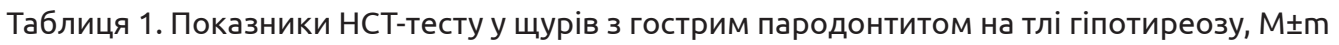

\begin{tabular}{|c|c|c|c|c|c|c|}
\hline \multirow{3}{*}{ Показник } & \multicolumn{6}{|c|}{ Група тварин } \\
\hline & \multirow{2}{*}{$\begin{array}{c}\text { інтактні } \\
\text { тварини, n=10 }\end{array}$} & \multirow{2}{*}{$\begin{array}{c}\text { гіпотиреоз, } \\
n=10\end{array}$} & \multicolumn{2}{|c|}{ гострий пародонтит } & \multicolumn{2}{|c|}{$\begin{array}{c}\text { гострий пародонтит + } \\
\text { гіпотиреоз }\end{array}$} \\
\hline & & & $\begin{array}{c}1 \text { доба } \\
n=7\end{array}$ & $\begin{array}{c}8 \text { доба } \\
n=7\end{array}$ & $\begin{array}{c}1 \text { доба } \\
n=7\end{array}$ & $\begin{array}{c}8 \text { доба } \\
n=7\end{array}$ \\
\hline сНСТ-тест, \% & $15,53 \pm 1,57$ & $\begin{array}{c}18,15 \pm 0,71 \\
p>0,05\end{array}$ & $\begin{array}{c}27,59 \pm 1,12 \\
p_{1}<0,001\end{array}$ & $\begin{array}{c}18,13 \pm 0,75 \\
p_{1}>0,05\end{array}$ & $\begin{array}{c}21,61 \pm 0,89 \\
p_{1}<0,01 \\
p_{2}<0,002\end{array}$ & $\begin{array}{c}13,11 \pm 0,41 \\
P_{1}>0,05 \\
P_{2}<0,001\end{array}$ \\
\hline іНСТ-тест, \% & $25,96 \pm 1,01$ & $\begin{array}{c}27,04 \pm 1,09 \\
p>0,05\end{array}$ & $\begin{array}{c}38,67 \pm 0,74 \\
p_{1}<0,001\end{array}$ & $\begin{array}{c}27,95 \pm 0,68 \\
p_{1}>0,05\end{array}$ & $\begin{array}{c}29,62 \pm 0,95 \\
p_{1}<0,02 \\
p_{2}<0,001\end{array}$ & $\begin{array}{c}17,24 \pm 0,54 \\
P_{1}<0,001 \\
P_{2}<0,002\end{array}$ \\
\hline$\Pi \mathrm{P}$ & $1,65 \pm 0,11$ & $\begin{array}{c}1,49 \pm 0,12 \\
p>0,05\end{array}$ & $\begin{array}{c}1,40 \pm 0,08 \\
p_{1}>0,05\end{array}$ & $\begin{array}{c}1,54 \pm 0,09 \\
p_{1}>0,05\end{array}$ & $\begin{array}{c}1,37 \pm 0,09 \\
P_{1}>0,05 \\
P_{2}>0,05\end{array}$ & $\begin{array}{c}1,31 \pm 0,06 \\
P_{1}<0,02 \\
P_{2}>0,05 \\
\end{array}$ \\
\hline $\mathrm{K}_{\text {акт }}$ & $0,401 \pm 0,014$ & $\begin{array}{c}0,329 \pm 0,012 \\
p<0,02\end{array}$ & $\begin{array}{c}0,277 \pm 0,009 \\
P_{1}<0,001\end{array}$ & $\begin{array}{c}0,351 \pm 0,011 \\
p_{1}<0,02\end{array}$ & $\begin{array}{c}0,270 \pm 0,008 \\
p_{1}<0,001 \\
p_{2}>0,05\end{array}$ & $\begin{array}{c}0,239 \pm 0,007 \\
p_{1}<0,001 \\
p_{2}<0,001\end{array}$ \\
\hline
\end{tabular}

Показник резерву у щурів з гіпотиреозом був на $11 \%$ нижчим, ніж у контролі. Більш суттєвих змін зазнав коефіцієнт активації нейтрофілів знизивсся на $21,9 \%(p<0,02)$. 
Огляди літератури, оригінальні дослідження, погляд на проблему, ювілеї

Розвиток запалення в яснах характеризувався збільшенням вмісту активних нейтрофілів у периферійній крові. На 1 добу від початку експерименту показники сНСТ-тесту були вищі на $78 \%$ ( $<<0,001)$, порівняно з контролем (рис. 1). У меншій мірі, на $49 \%(p<0,001)$ змінилися показники індукованого НСТ-тесту, показник резерву склав $(1,40 \pm 0,08)$, що на $18 \%$ менше, ніж у контролі. Зменшення показника резерву відображає зниження функціональних резервів нейтрофілів, характерне для запа- лення. На це ж вказує і суттєве зниження коефіцієнта метаболічної активації нейтрофілів (69 \% від рівня здорових тварин). На 8 добу з моменту нанесення травми показники сНСТ-тесту й іНСТ-тесту знизилися майже до рівня інтактних щурів. ПР на 8-му добу з моменту нанесення ушкодження залишався нижчим контрольних значень $(1,54 \pm 0,09$, p>0,05), а коефіцієнт резерву такождещо збільшився порівняно з 1-ю добою, однак був достовірно нижчим, ніж у контрольних тварин (87 \% від норми).

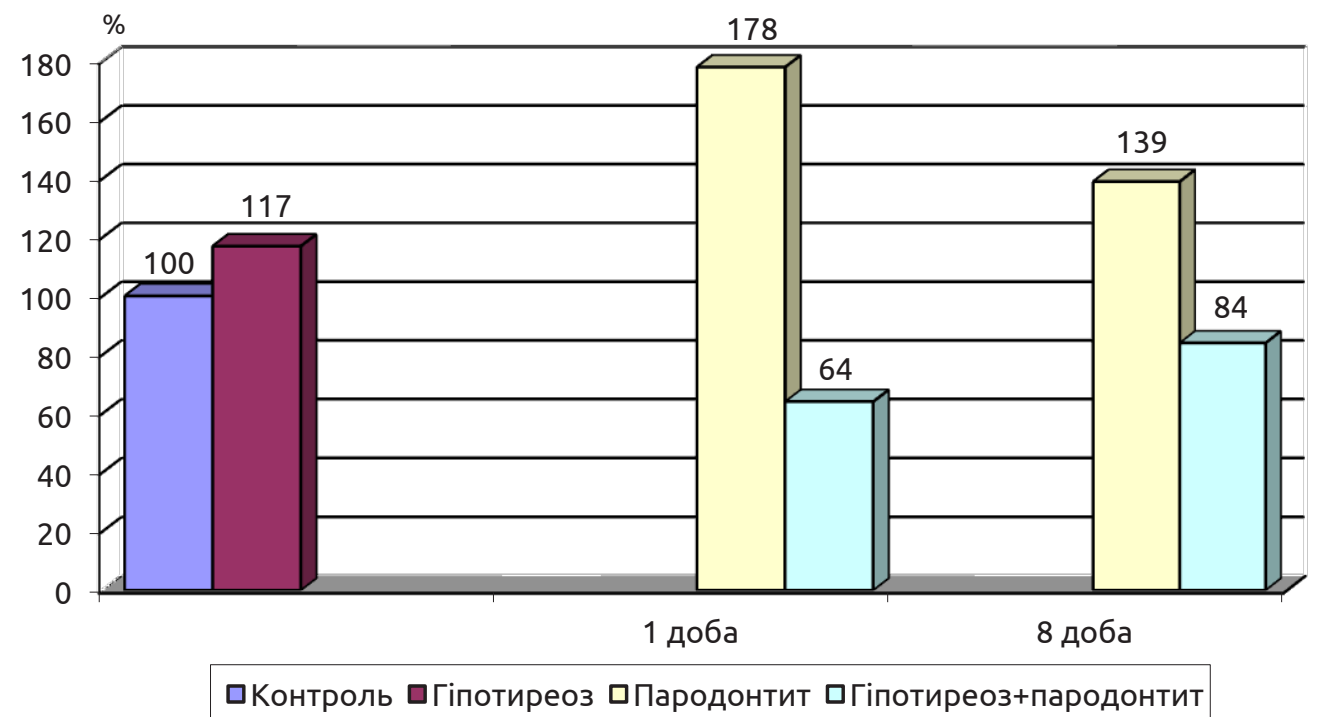

Рис. 1. Показники спонтанного НСТ-тесту у тварин з гострим пародонтитом та на тлі гіпотиреозу.

В експериментах in vivo та in vitro показано зниження продукції супероксидного аніон-радикала на фоні гіпотиреозу, що відповідає отриманим нами результатам [15]. Дослідження функціональної активності нейтрофілів периферійної крові у щурів із запаленням, що триває на тлі гіпотиреозу, показало зниження інтенсивності дихального вибуху в поліморфноядерних лейкоцитах. На всіх термінах експерименту значення як спонтанного, так і стимульованого НСТ-тесту (див. табл. 1) були нижчими, ніж у тварин, у яких запальний процес перебігав без зміни гормонального фону. На першу добу експерименту у щурів з гіпотиреозом показники сНСТ-тесту та іНСТ-тесту були достовірно нижчими, в 1,38 раза i 1,31 раза відповідно. Показник резерву, а також коефіцієнт активації нейтрофілів через добу від моменту нанесення травми в порівнюваних групах суттєво не відрізнялись. Через 8 діб з моменту ушкодження ясен у щурів з гіпотиреозом показники НСТтесту знизилися, що супроводжувалося зменшенням показника резерву до $(1,31 \pm 0,06)$ і $\mathrm{K}_{\text {акт }}$ до $(0,239 \pm 0,007)$. У цей термін експерименту значення сНСТ-тесту й іНСТ-тесту були нижчими в 1,39 раза і 1,64 раза, порівняно $з$ тваринами, у яких запалення перебігало без порушень гормонального фону.

Зниження оксигензалежної біоцидності нейтрофілів супроводжувалося посттравматичними нагноєннями, відсоток яких до 8 доби в групі щурів з незміненим гормональним фоном склав 56,4 \%. Більш низькі показники НСТ-тесту і рівня продуктів ліпідної пероксидації у щурів з гіпотиреозом супроводжувалися зменшенням посттравматичних нагноєнь в 1,5 раза.

Аналіз показників клітинного імунітету у досліджуваних групах вказує на суттєві відмінності між досліджуваними групами тварин (рис. 2). У тварин з гіпотиреозом показник CD-4 лімфоцитів був на 39 \% нижчим, ніж у здорових тварин. Дещо менше знизився показник CD-8 лімфоцитів - на 14 \% від норми, що призвело до зниження імунорегуляторного індексу з $(1,51 \pm 0,04)$ до $(1,23 \pm 0,05)$. На сьогодні рівень імунорегуляторного індексу оцінюють у зіставленні з фазою імунної відповіді. У період розпалу клінічних проявів запального процесу імунорегуляторний індекс сягає високих значень за рахунок великого відсоткового вмісту Т-хелперів (CD4+ Т-клітин). У період реконвалесценції значення показника зменшується у зв'язку 
Огляди літератури, оригінальні дослідження, погляд на проблему, ювілеї з наростанням рівня CD8 ${ }^{+}$Т-клітин (кілерів). Порушення такої закономірності свідчить про неадек-

ватність імунної реакції та про можливість хронізації процесу через неповну ерадикацію збудника.

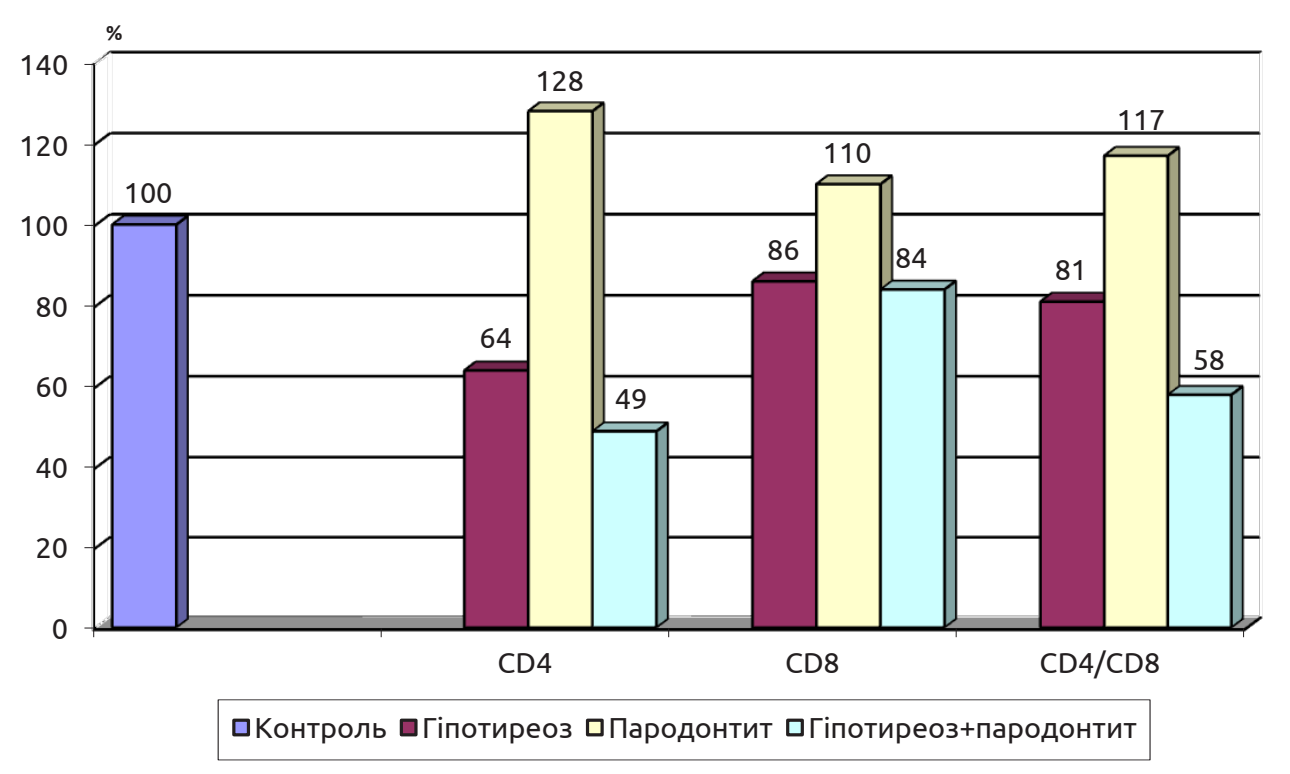

Рис. 2. Показники клітинної ланки імунної системи у тварин з гострим пародонтитом та на тлі гіпотиреозу (1 доба).

Моделювання нами гострого пародонтиту супроводжувалося різноспрямованими змінами показників клітинного імунітету. Зокрема, на 1 добу в еутиреоїдних тварин показник CD-4 склав $128 \%$ від рівня здорових, а CD-8-110\%, що спричинило зростання імунорегуляторного індексу в 1,17 раза. Достовірні зміни ми відмітили і на 8 добу - CD-4 склав 121 \% від норми, CD-8 - $105 \%$. Такі зміни виражалися у дещо меншому зростанні співвідношення CD-4/CD-8, яке становило $(1,74 \pm 0,04)$. Отже, в еутиреоїдних щурів спостерігається нормальний перебіг запального процесу із переважанням зростання Т-хелперів над рівнем цитотоксичних
Т-лімфоцитів і, відповідно, зростанням імунорегуляторного індексу. У тварин, яким гострий пародонтит моделювали на тлі гіпотиреозу, зміни мали протилежний напрямок. Вміст CD-4 лімфоцитів на 1 добу, порівняно зі здоровими тваринами, вірогідно знизився і склав 55 \% від їх рівня, що спричинило значне зниження імунорегуляторного індексу - відповідно до $(0,96 \pm 0,03)$, що склало 63 \% від показника здорових тварин. На 8 добу експерименту показник CD-4-клітин був ще меншим, становлячи 49 \% від норми, а CD-8 - 81 \%. Імунорегуляторний індекс знизився ще більше і склав $(0,87 \pm 0,02)$, що на 74 \% менше, ніж у інтактних тварин (табл. 2).

Таблиця 2. Показники клітинної ланки імунітету у тварин з гострим пародонтитом на тлі гіпотиреозу, $\mathrm{M} \pm \mathrm{m}$

\begin{tabular}{|c|c|c|c|c|c|c|}
\hline \multirow{3}{*}{ Показник } & \multicolumn{6}{|c|}{ Група тварин } \\
\hline & \multirow{2}{*}{$\begin{array}{c}\text { інтактні } \\
\text { тварини, } \\
\text { n=10 }\end{array}$} & \multirow{2}{*}{$\begin{array}{c}\text { гіпоти- } \\
\text { реоз, } \\
n=10\end{array}$} & \multicolumn{2}{|c|}{ гострий пародонтит } & \multicolumn{2}{|c|}{ гострий пародонтит + гіпотиреоз } \\
\hline & & & $\begin{array}{c}1 \text { доба } \\
\mathrm{n}=7\end{array}$ & $\begin{array}{c}8 \text { доба } \\
n=7\end{array}$ & $\begin{array}{c}1 \text { доба } \\
\mathrm{n}=7\end{array}$ & $\begin{array}{c}8 \text { доба } \\
n=7\end{array}$ \\
\hline 1 & 2 & 3 & 4 & 5 & 6 & 7 \\
\hline$C D-4, \%$ & $\begin{array}{c}39,43 \pm \\
1,26\end{array}$ & $\begin{array}{c}28,32 \pm 0,81 \\
p<0,001\end{array}$ & $\begin{array}{c}50,49 \pm 0,87 \\
P<0,001 \\
P_{1}<0,001\end{array}$ & $\begin{array}{c}47,73 \pm 1,39 \\
p<0,05 \\
p_{2}<0,001\end{array}$ & $\begin{array}{c}21,61 \pm 0,90 \\
\mathrm{p}<0,001 \\
\mathrm{p}_{1}<0,001 \\
\mathrm{p}_{3}<0,001\end{array}$ & $\begin{array}{c}19,51 \pm 1,07 \\
p<0,001 \\
p_{1}<0,001 \\
p_{2}>0,05 \\
p_{3}<0,001\end{array}$ \\
\hline$C D-8, \%$ & $\begin{array}{c}26,03 \pm \\
1,43\end{array}$ & $\begin{array}{c}22,85 \pm 1,10 \\
p<0,01\end{array}$ & $\begin{array}{c}28,59 \pm 0,86 \\
p>0,05 \\
p_{1}>0,05\end{array}$ & $\begin{array}{c}27,33 \pm 0,68 \\
p<0,001 \\
p_{2}<0,001\end{array}$ & $\begin{array}{c}22,31 \pm 0,77 \\
p>0,05 \\
p_{1}<0,001 \\
p_{3}<0,001\end{array}$ & $\begin{array}{c}21,21 \pm 0,50 \\
p<0,05 \\
p_{1}<0,001 \\
p_{2}<0,01 \\
p_{3}>0,05\end{array}$ \\
\hline
\end{tabular}




\begin{tabular}{|l|c|c|c|c|c|c|}
\hline \multicolumn{1}{|c|}{1} & 2 & 3 & 4 & 5 & 6 & 7 \\
\hline Імунорегу- & $1,51 \pm 0,04$ & $1,23 \pm 0,05$ & $1,77 \pm 0,06$ & $1,74 \pm 0,04$ & $0,96 \pm 0,03$ & $0,87 \pm 0,02$ \\
ляторний & & $\mathrm{p}<0,001$ & $\mathrm{p}<0,001$ & $\mathrm{p}<0,001$ & $\mathrm{p}<0,01$ & $\mathrm{p}<0,001$ \\
індекс & & & $\mathrm{p}_{1}<0,001$ & $\mathrm{p}_{2}>0,05$ & $\mathrm{p}_{1}<0,05$ & $\mathrm{p}_{1}>0,05$ \\
CD-4/CD-8 & & & & & $\mathrm{p}_{3}<0,001$ & $\mathrm{p}_{2}>0,05$ \\
& & & & & & $\mathrm{p}_{3}<0,001$ \\
\hline
\end{tabular}

Таким чином, у тварин з пародонтитом на тлі гіпотиреозу виявляється суттєве зниження CD-4лімфоцитів, порушення співвідношення основних субпопуляцій лімфоцитів (CD-4 і CD-8), що супроводжується достовірним зниженням імунорегуляторного індексу. Виявлена недостатність клітинної ланки імунної відповіді відображає посилення взаємного негативного впливу запального процесу в пародонті і системних порушень імунного захисту за умов супутнього дефіциту гормонів щитоподібної залози.

3 метою оцінки стану гуморального імунітету щитоподібної залози при моделюванні гіпотиреозу було визначено вміст IgG, IgM i IgA у сиро- ватці крові за допомогою біохімічного аналізатора STAT FAX (USA). Встановлено (табл. 3) статистично значиме зниження рівня досліджуваних показників у тварин, яким протягом 14 діб вводили мерказоліл, зокрема рівень IgG зменшився в 1,8 раза, IgM - в 1,6 раза i IgA - в 1,7 раза $(p<0,01)$. Враховуючи дані про регуляторну роль тиреоїдних гормонів в імуногенезі, вважаємо, що власне порушення функціонального стану щитоподібної залози зумовлює зниження гуморальної імунної відповіді при антигенній стимуляції. Це підтверджує існуючі дані про те, що гіпотиреоз супроводжується розвитком вторинних імунодефіцитів [16].

Таблиця 3. Показники гуморальної ланки імунітету у тварин з гострим пародонтитом на тлі гіпотиреозу, Мџm

\begin{tabular}{|c|c|c|c|c|c|c|}
\hline \multirow{3}{*}{ Показник, г/л } & \multicolumn{6}{|c|}{ Група тварин } \\
\hline & \multirow{2}{*}{$\begin{array}{c}\text { інтактні } \\
\text { тварини, n=10 }\end{array}$} & \multirow{2}{*}{$\begin{array}{c}\text { гіпотиреоз, } \\
n=10\end{array}$} & \multicolumn{2}{|c|}{ гострий пародонтит } & \multicolumn{2}{|c|}{$\begin{array}{l}\text { гострий пародонтит + } \\
\text { гіпотиреоз }\end{array}$} \\
\hline & & & $\begin{array}{c}1 \text { доба } \\
\text { n=7 }\end{array}$ & $\begin{array}{c}8 \text { доба } \\
n=7\end{array}$ & $\begin{array}{c}1 \text { доба } \\
\text { n=7 }\end{array}$ & $\begin{array}{c}8 \text { доба } \\
n=7\end{array}$ \\
\hline $\lg G$ & $6,75 \pm 0,14$ & $\begin{array}{c}3,85 \pm 0,08 \\
p<0,001\end{array}$ & $\begin{array}{c}8,50 \pm 0,16 \\
\mathrm{p}<0,001 \\
\mathrm{P}_{1}<0,001\end{array}$ & $\begin{array}{c}7,25 \pm 0,13 \\
p<0,05 \\
p_{2}<0,001\end{array}$ & $\begin{array}{c}5,13 \pm 0,13 \\
p<0,001 \\
p_{1}<0,001 \\
P_{3}<0,001\end{array}$ & $\begin{array}{c}5,42 \pm 0,18 \\
\mathrm{P}<0,001 \\
\mathrm{P}_{1}<0,001 \\
\mathrm{P}_{2}>0,05 \\
\mathrm{P}_{3}<0,001\end{array}$ \\
\hline $\lg M$ & $3,02 \pm 0,17$ & $\begin{array}{c}1,90 \pm 0,11 \\
\mathrm{p}<0,01\end{array}$ & $\begin{array}{c}6,08 \pm 0,15 \\
\mathrm{p}<0,001 \\
\mathrm{p}_{1}<0,001\end{array}$ & $\begin{array}{c}3,65 \pm 0,11 \\
\mathrm{p}<0,001 \\
\mathrm{p}_{2}<0,001\end{array}$ & $\begin{array}{c}2,82 \pm 0,12 \\
p>0,05 \\
p_{1}<0,001 \\
p_{3}<0,001\end{array}$ & $\begin{array}{c}3,50 \pm 0,22 \\
\mathrm{p}<0,05 \\
\mathrm{P}_{1}<0,001 \\
\mathrm{P}_{2}<0,01 \\
\mathrm{P}_{3}>0,05\end{array}$ \\
\hline $\lg A$ & $1,77 \pm 0,06$ & $\begin{array}{c}1,03 \pm 0,05 \\
p<0,001\end{array}$ & $\begin{array}{c}2,50 \pm 0,05 \\
p<0,001 \\
p_{1}<0,001\end{array}$ & $\begin{array}{c}2,33 \pm 0,11 \\
p<0,001 \\
p_{2}>0,05\end{array}$ & $\begin{array}{c}1,30 \pm 0,09 \\
\mathrm{p}<0,01 \\
\mathrm{P}_{1}<0,05 \\
\mathrm{P}_{3}<0,001\end{array}$ & $\begin{array}{c}1,23 \pm 0,06 \\
\mathrm{P}<0,001 \\
\mathrm{P}_{1}>0,05 \\
\mathrm{P}_{2}>0,05 \\
\mathrm{P}_{3}<0,001\end{array}$ \\
\hline
\end{tabular}

Примітка. Тут ів попередніх таблицях: $\mathrm{p}-$ достовірність різниці тварин досліднихгруп відносно інтактних тварин; $\mathrm{p}_{1}-$ достовірність різниці тварин дослідних груп відносно гіпотиреоїдних тварин; $\mathrm{p}_{2}$ - достовірність різниці показників у відповідні доби дослідження в межах однієї експериментальної моделі; $\mathrm{p}_{3}$ - достовірність різниці еутиреоїдних і гіпотиреоїдних тварин 3 гострим пародонтитом у відповідні доби дослідження.

Як показали наші дослідження, у тварин 3 гострим пародонтитом на 1 добу рівень IgG був вищий на 25,9\%, IgM - на 101,3\% і IgA - на 41,2\%, порівняно з контрольною групою. Активація гуморального імунітету з надлишковим синтезом всіх імуноглобулінів у крові свідчить про ендотоксемію й антигенемію за умови експеримен- тального гострого пародонтиту. Через 7 діб після гострої механічної травми м'яких тканин ясен спостерігалося зниження рівнів IgG на 27,6 \%, IgM - на 40,0 \% при практично незмінному показнику IgA відносно даних на 1 добу. Варто зазначити, що вміст IgG у сироватці крові щурів з гострим пародонтитом на 8 добу був вищий, ніж в 
Огляди літератури, оригінальні дослідження, погляд на проблему, ювілеї

інтактних тварин, на 7,4 \%, IgM - на 20,8 \% й IgG на $31,6 \%(p<0,05-0,001)$ (рис. 3). Отримані показники гуморальної ланки імунітету у тварин з гострим пародонтитом свідчать про те, що на 1 добу відбувалася активація мобілізації імуно- глобулінів з кровоносного русла 3 наступним зривом адаптаційних механізмів, що проявлялось пригніченням секреції IgG, IgM i IgA на системному рівні, вміст яких, проте, не досягав показників інтактних тварин.

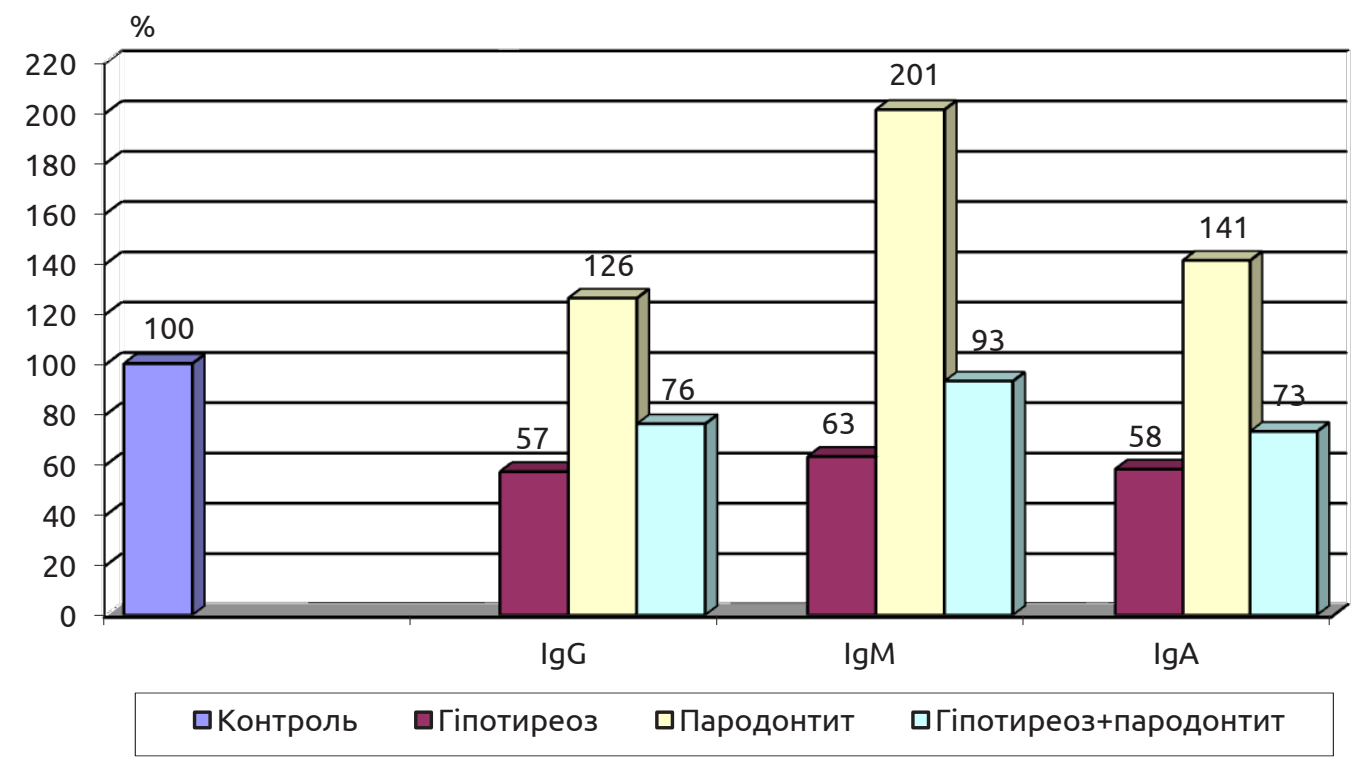

Рис. 3. Показники гуморальної ланки імунної системи у тварин з гострим пародонтитом та на тлі гіпотиреозу (8 доба).

За умови модельованого гострого пародонтиту на тлі гіпотиреозу відмічалося пригнічення гуморальної ланки імунної системи вже на 1 добу, яке характеризувалось достовірним зниженням імуноглобулінів усіх класів. Так, вміст IgG у сироватці крові був менший в 1,7 раза , IgM-у 2,2 раза й IgA - в 1,9 раза стосовно групи контролю $(p<0,001)$.

В експериментальних тварин при пародонтиті на тлі гіпотиреозу вміст імуноглобулінів усіх класів був достовірно вищим, ніж у групі тварин 3 модельованим гіпотиреозом, проте значно меншим, ніж вміст IgG, IgM i IgA у групі тварин з гострим пародонтитом на 65,7 \%, 166,7 \% і $92,3 \%$ відповідно. На 8 добу експерименту на фоні гіпотиреозу і пародонтиту вміст IgM зріс на 24,1 \% відносно даних на 1 добу при практично незмінних IgC i IgA. Поєднання гіпотиреозу і пародонтиту зумовлювало зростання на 8 добу імуноглобулінів класу G на 33,8 \% й A - на 89,4 \% відносно даних групи з гострим пародонтитом на цю ж добу $(p<0,001)$.

При дослідженні взаємозв'язку між гормональним статусом та рівнем імуноглобулінів встановлено прямий сильний кореляційний зв'язок між концентрацією тиреоїдних гормонів та вмістом IgG, IgM i IgA у групі тварин з гіпотиреозом, який зберігався у щурів за умови гострого паро- донтиту на фоні гіпотиреозу на 1 добу (табл. 4). Потрібно зазначити, що на 8 добу експерименту на гуморальну ланку імунної системи діють обидва патогенетичних чинники - гіпотиреоз і гострий пародонтит, тоді як на 1 добу більший внесок у розвиток дисбалансу імуноглобулінів на системному рівні робить дисфункція щитоподібної залози.

У науковій літературі $\epsilon$ дані щодо впливу тиреоїдних гормонів на імунну систему організму $[6,14]$. Відомо, що зниження концентрації гормонів щитоподібної залози призводить до імунодефіциту, який посилює імунопатологічний вплив на залозу, сприяє прогресуванню автоімунних процесів і, відповідно, гіпотиреозу. 3 іншої сторони, численні дослідження показали виражену активацію В-клітинної ланки імунної системи у поєднанні з низькою ефективністю гуморальної відповіді при пародонтиті $[14,15]$.

Висновки. 1. Поєднання двох досліджуваних патологій поглиблює імунодепресію вже на 1 добу експерименту, при цьому основний вплив на імунологічні показники має гормональний фон, зокрема тироксин, трийодтиронін і тиреотропний гормон. Статистично значиме зростання вмісту імуноглобулінів на 8 добу проти даних 1 доби досліду може вказувати на гіперергічну реактивність місцевого імунітету, що зумовлює вихід імуноглобулінів у системний кровотік. Функціону- 
Огляди літератури, оригінальні дослідження, погляд на проблему, ювілеї

Таблиця 4. Кореляційні зв'язки між показниками тиреоїдних гормонів за умови гіпотиреозу й імуноглобулінами класів A, M, G у крові тварин з гострим пародонтитом на тлі гіпотиреозу

\begin{tabular}{|c|c|c|c|c|}
\hline \multicolumn{2}{|c|}{ Кореляційні зв'язки } & \multirow{2}{*}{$\begin{array}{c}\text { Дослідні групи } \\
\text { гіпотиреоз }\end{array}$} & \multirow{2}{*}{$\begin{array}{c}\text { Коефіцієнт кореляції, } \\
\Gamma_{\text {xу }} \\
0,73 \\
\end{array}$} & \multirow{2}{*}{$\begin{array}{c}\text { Вірогідність } \\
\text { кореляційного зв'язку, р } \\
<0,05\end{array}$} \\
\hline \multirow[t]{9}{*}{$\lg G$, г/л } & \multirow[t]{3}{*}{ ТЗ, пкмоль/л } & & & \\
\hline & & $\begin{array}{c}\text { гострий пародонтит на тлі } \\
\text { гіпотиреозу, } 1 \text { доба }\end{array}$ & 0,76 & $<0,05$ \\
\hline & & $\begin{array}{l}\text { гострий пародонтит на тлі } \\
\text { гіпотиреозу, } 7 \text { доба }\end{array}$ & 0,44 & $>0,05$ \\
\hline & \multirow[t]{3}{*}{ Т4, пкмоль/л } & гіпотиреоз & 0,72 & $<0,05$ \\
\hline & & $\begin{array}{c}\text { гострий пародонтит на тлі } \\
\text { гіпотиреозу, } 1 \text { доба }\end{array}$ & 0,79 & $<0,05$ \\
\hline & & $\begin{array}{l}\text { гострий пародонтит на тлі } \\
\text { гіпотиреозу, } 7 \text { доба }\end{array}$ & 0,71 & $<0,05$ \\
\hline & \multirow[t]{3}{*}{ ТТГ, пкмоль/л } & гіпотиреоз & 0,79 & $<0,05$ \\
\hline & & $\begin{array}{l}\text { гострий пародонтит на тлі } \\
\text { гіпотиреозу, } 1 \text { доба }\end{array}$ & 0,78 & $<0,05$ \\
\hline & & $\begin{array}{l}\text { гострий пародонтит на тлі } \\
\text { гіпотиреозу, } 7 \text { доба }\end{array}$ & 0,57 & $>0,05$ \\
\hline \multirow[t]{9}{*}{$\lg M, г / л$} & \multirow[t]{3}{*}{ Т3, пкмоль/л } & гіпотиреоз & 0,74 & $<0,05$ \\
\hline & & $\begin{array}{c}\text { гострий пародонтит на тлі } \\
\text { гіпотиреозу, } 1 \text { доба }\end{array}$ & 0,80 & $<0,05$ \\
\hline & & $\begin{array}{c}\text { гострий пародонтит на тлі } \\
\text { гіпотиреозу, } 7 \text { доба }\end{array}$ & 0,54 & $>0,05$ \\
\hline & \multirow[t]{3}{*}{ Т4, пкмоль/л } & гіпотиреоз & 0,72 & $<0,05$ \\
\hline & & $\begin{array}{l}\text { гострий пародонтит на тлі } \\
\text { гіпотиреозу, } 1 \text { доба }\end{array}$ & 0,80 & $<0,05$ \\
\hline & & $\begin{array}{l}\text { гострий пародонтит на тлі } \\
\text { гіпотиреозу, } 7 \text { доба }\end{array}$ & 0,56 & $>0,05$ \\
\hline & \multirow[t]{3}{*}{ ТТГ, пкмоль/л } & гіпотиреоз & 0,78 & $<0,05$ \\
\hline & & $\begin{array}{l}\text { гострий пародонтит на тлі } \\
\text { гіпотиреозу, } 1 \text { доба }\end{array}$ & 0,72 & $<0,05$ \\
\hline & & $\begin{array}{c}\text { гострий пародонтит на тлі } \\
\text { гіпотиреозу, } 7 \text { доба }\end{array}$ & 0,32 & $>0,05$ \\
\hline \multirow[t]{9}{*}{$\lg A$, г/л } & \multirow[t]{3}{*}{ ТЗ, пкмоль/л } & гіпотиреоз & 0,82 & $<0,05$ \\
\hline & & $\begin{array}{c}\text { гострий пародонтит на тлі } \\
\text { гіпотиреозу, } 1 \text { доба }\end{array}$ & 0,78 & $<0,05$ \\
\hline & & $\begin{array}{c}\text { гострий пародонтит на тлі } \\
\text { гіпотиреозу, } 7 \text { доба }\end{array}$ & 0,44 & $>0,05$ \\
\hline & \multirow[t]{3}{*}{ Т4, пкмоль/л } & гіпотиреоз & 0,71 & $<0,05$ \\
\hline & & $\begin{array}{c}\text { гострий пародонтит на тлі } \\
\text { гіпотиреозу, } 1 \text { доба }\end{array}$ & 0,78 & $<0,05$ \\
\hline & & $\begin{array}{l}\text { гострий пародонтит на тлі } \\
\text { гіпотиреозу, } 7 \text { доба }\end{array}$ & 0,51 & $>0,05$ \\
\hline & \multirow[t]{3}{*}{ ТТГ, пкмоль/л } & гіпотиреоз & 0,77 & $<0,05$ \\
\hline & & $\begin{array}{c}\text { гострий пародонтит на тлі } \\
\text { гіпотиреозу, } 1 \text { доба }\end{array}$ & 0,75 & $<0,05$ \\
\hline & & $\begin{array}{l}\text { гострий пародонтит на тлі } \\
\text { гіпотиреозу, } 7 \text { доба }\end{array}$ & 0,60 & $>0,05$ \\
\hline
\end{tabular}

вання імунної системи у режимі напруження може свідчити про зрив адаптації за умови гострого пародонтиту на тлі гіпотиреозу.

2. За умови експериментального гострого пародонтиту на фоні гіпотиреозу відбуваються пору- шення функціонування імунної системи, які характеризуються імунодепресією на 1 добу досліду та гіперергічною реактивністю місцевого імунітету на 8 добу, що зумовлює вихід імуноглобулінів у системний кровотік. При гострому пародонтиті на 
Огляди літератури, оригінальні дослідження, погляд на проблему, ювілеї

тлі мерказоліл-індукованого гіпотиреозу на 1 добу експерименту вагомий внесок у розвиток дисбалансу імуноглобулінів на системному рівні робить дисфункція щитоподібної залози, тоді як на 8 добу досліду на гуморальну ланку імунної системи діють обидва патогенетичних чинники - гіпотиреоз і гострий пародонтит.

\section{ЛІТЕРАТУРА}

1. Адекенов С. М. Современное состояние и перспективы производства фитопрепаратов в Казахстане / С. М. Адекенов // Российские аптеки. - 2003. - № 5. C. 61-64.

2. Ветра Я. Я. Цитокины / Я. Я. Ветра, Л. В. Иванова, И. Э. Крейле // Гематол. и трансфузиол. - 2000. - Т. 45, № 4. - С. 45-49.

3. Сравнительная оценка иммунологического профиля больных с аутоимунными заболеваниями щитовидной железы / Е. Ю. Гусева, В. А. Черешнев, Е. Ю. Гусев, В. Н. Шершнев // Вестник Уральской медицинской академии наук. - 2008. - № 1. - С. 16-19.

4. Клиническая иммунология : учебник для студентов медицинских вузов / под ред. А. В. Караулова. - М. : Медицинское информационное агенство, 1999. - 604 с.

5. Лапач С. Н. Статистические методы в медико-биологических исследованиях с использованием Excel / С. Н. Лапач, А. В. Чубенко, П. Н. Бабич. - К. : Морион, 2000. -320 c.

6. Москвина Т. С. Эффективность лечения пародонтита у больных с нарушением функции щитовидной железы / Т. С. Москвина // Стоматология. - 2001. - № 1. C. $47-50$.

7. Науково-практичні рекомендації з утримання лабораторних тварин та роботи з ними / Ю. М. Кожем'якін, О. С. Хромов, М. А. Філоненко Г. А. Сайфетдінова. - К. : Авіцена, 2002. - 156 с.

8. Патент на корисну модель № 65771: В. Р. Мачоган, О. В. Авдєєв / Спосіб моделювання пародонтиту // Бюлетень № 23. - 2011 p.

\section{REFERENCES}

1. Adekenov, S.M. (2003). Sovremennoye sostoyaniye i perspektivy proizvodstva fitopreparatov v Kazakhstane [The current state and prospects for the production of phytopreparations in Kazakhstan]. Rossiyskiye apteki Russian Pharmacies, 5, 61-64 [in Russian].

2. Vetra, Ya.Ya., Ivanova, L.V. \& Kreyle, I.E. (2000). Tsitokiny [Cytokines]. Gematol. i transfuziol. - Hematology and Transfusiology, 45 (4), 45-49 [in Russian].

3. Guseva, Ye.Yu., Chereshnev, V.A., Gusev, Ye.Yu., \& Shershnev, V.N. (2008). Sravnitelnaya otsenka immunologicheskogo profilya bolnykh s autoimunnymi zabolevaniyami shchitovidnoy zhelezy [Comparative evaluation of the immunological profile of patients with autoimmune diseases of the thyroid gland]. Vestnik Uralskoy meditsinskoy
Перспективи подальших досліджень. У перспективі передбачається провести дослідження патоморфологічних змін слизової оболонки ясен щурів за умови експериментального гострого пародонтиту на тлі гіпотиреозу.

9. Роль цитокинов в механизмах развития хронического воспаления в тканях пародонта / Л. В. Ковальчук, Л. В. Ганковская, М. А. Рогова [и др.] // Иммунология. -2000 . - № 6. - С. 24-26.

10. Рыболовлев Ю. Р. Дозирование веществ для млекопитающих по константам биологической активности / Ю. Р. Рыболовлев, Р. С. Рыболовлев // Доклады АН СССР - 1979. - T. 247, № 6. - C. 1513-1516.

11. Фадеев В. В. Профессиональный взгляд на проблему гипотиреоза / В. В. Фадеев // Лечащий врач. 2005. - № 5. - С. 26-29.

12. Шнейдер О. Л. Заболевания пародонта при гипофункции щитовидной железы / О. Л. Шнейдер, В. П. Журавлев//Уральский стоматологический журнал.-2004.№ 6. - C. 31-32.

13. Caruso T. J. Treatment of the common cold with Echinacea: a structured review / T. J. Caruso, J. M. Gwaltney // Clin. Infect. Dis. - 2005.- Vol. 40. - P. 807-810.

14. Differential response of Porphyromonas gingivalis to varying levels and duration of hydrogen peroxide-induced oxidative stress / R. M. McKenzie, N. A. Johnson, W. Aruni [et al.] // Microbiology. - 2012. - Vol. 158. - P. 2465-2479.

15. Distinct and complex bacterial profiles in human periodontitis and health revealed by $16 \mathrm{~S}$ pyrosequencing / A. L. Griffen, C. J. Beall, J. H. Campbell [et al.] // ISME J. 2012. - Vol. 6. - P. 1176-1185.

16. Isman C. A. Methimazole-induced hypothyroidism in rats ameliorates oxidative injury in experimental colitis / C. A. Isman, B. C. Yegen, I. Alican // J. Endocrinol. - 2003. Vol. 177, No. 3. - P. 471-476.

akademii nauk - Bulletin of the Ural Medical Academy of Sciences, 1, 16-19 [in Russian].

4. Karaulova, A.V. (Ed.) (1999). Klinicheskaya immunologiya: uchebnik dlya studentov meditsinskikh vuzov [Clinical immunology: a textbook for students of medical universities]. Moscow: Meditsinskoye informatsionnoye agenstvo [in Russian].

5. Lapach, S.N., Chubenko, A.V., \& Babich, P.N. (2000). Statisticheskiye metody $v$ mediko-biologicheskikh issledovaniyakh s ispolzovaniyem Excel [Statistical methods in biomedical research using Excel]. Kyiv: Morion [in Russian].

6. Moskvina, T.S. (2001). Effektivnost lecheniya parodontita u bolnykh s narusheniyem funktsii shchitovidnoy zhelezy [The effectiveness of the treatment of periodon- 
Огляди літератури, оригінальні дослідження, погляд на проблему, ювілеї

titis in patients with impaired thyroid function]. Stomatologiya - Dentistry, 1, 47-50 [in Russian].

7. Kozhemiakin, Yu.M., Khromov, O.S., Filonenko, M.A., \& Sayfetdinova, H.A. (2002). Naukovo-praktychni rekomendatsii z utrymannia laboratornykh tvaryn ta roboty z nymy [Scientific and practical recommendations for the maintenance of laboratory animals and work with them]. Kyiv: Avitsena [in Ukrainian].

8. Machohan, V.R., \& Avdieiev, O.V. (2011). Patent na korysnu model № 65771: Sposib modeliuvannia parodontytu [Patent for Utility Model No. 65771: Method of Periodontal Modeling]. Byuleten - Bulletin, 23 [in Ukrainian].

9. Kovalchuk, L.V., Gankovskaya, L.V., Rogova, M.A., Ivanyushko, T.P., Budanovoy, Ye.V., \& Shabanovoy, N.V. (2000). Rol tsitokinov v mekhanizmakh razvitiya khronicheskogo vospaleniya $v$ tkanyakh parodonta [The role of cytokines in the mechanisms of development of chronic inflammation in periodontal tissues]. Immunologiya-Immunology, 6, 24-26 [in Russian].

10. Rybolovlev, Yu.R., \& Rybolovlev, R.S. (1979). Dozirovaniye veshchestv dlya mlekopitayushchikh po konstantam biologicheskoy aktivnosti [Dose of substances for mammals according to the biological activity]. Doklady Akademii nauk SSSR - Reports of the USSR Academy of Sciences, 247, 6, 1513-1516 [in Russian].
11. Fadeyev, V.V. (2005). Professionalnyy vzglyad na problemu gipotireoza [Professional view on the problem of hypothyroidism]. Lechashchiy vrach - Attending Physician, 5, 26-29 [in Russian].

12. Shnayder, O.L., \& Zhuravlev, V.P. (2004). Zabolevaniya parodonta pri gipofunktsii shchitovidnoy zhelezy [Periodontal diseases in thyroid gland hypofunction]. Uralskiy stomatologicheskiy zhurnal - Ural Dental Journal, 6, 3132 [in Russian].

13. Caruso, T.J., \& Gwaltney, J.M. (2005). Treatment of the common cold with Echinacea: a structured review. Clin. Infect. Dis., 40, 807-810.

14. McKenzie, R.M.E., Johnson, N.A., Aruni, W., Dou, Yu., Masinde, G., \& Fletcher, H.M. (2012). Differential response of Porphyromonas gingivalis to varying levels and duration of hydrogen peroxide-induced oxidative stress. Microbiology, 158, 2465-2479.

15. Griffen, A.L., Beall, C.J., Campbell, J.H., Firestone, N.D., Kumar, P.S., Yang, Z.K., ... \& Leys, E.J. (2012). Distinct and complex bacterial profiles in human periodontitis and health revealed by $16 \mathrm{~S}$ pyrosequencing. ISME J., 6 , 1176-1185.

16. Isman, C.A., Yegen, B.C., \& Alican, I. (2003). Methimazole-induced hypothyroidism in rats ameliorates oxidative injury in experimental colitis. J. Endocrinol., 177, 3, 471-476.

\title{
ОСОБЕННОСТИ НЕСПЕЦИФИЧЕСКИХ И СПЕЦИФИЧЕСКИХ ЗВЕНЬЕВ ИММУННОЙ ЗАЩИТЫ У КРЫС С ОСТРЫМ ПАРОДОНТИТОМ НА ФОНЕ ГИПОТИРЕОЗА
}

\author{
ФТ. И. Дзецюх \\ ГВУЗ «Тернопольский государственный медицинский университет имени И. Я. Горбачевского \\ МОЗ Украины»
}

РЕЗЮМЕ. Для изучения влияния экспериментального гипотиреоза на состояние неспецифического и специфического звеньев иммунной защиты у крыс с острой травмой мягких тканей десны было проведено определение НCT-теста, показателей клеточного звена иммунной системы (CD4, CD8), а также исследовано содержание IgG, IgM и IgA в сыворотке крови на анализаторе STAT FAX (USA).

Цель - изучить особенности неспецифического и специфического звеньев иммунной защиты у крыс с острым пародонтитом на фоне гипотиреоза.

Материал и методы. Гипотиреоз у крыс вызывали введением мерказолила в дозе 25 мг/кг в течение 21 суток. Контроль осуществляли по уровням тироксина, трийодтиронина и тиреотропного гормона, а также по массе животных и их двигательной активности. В группу сравнения входили животные, которым мерказолил не применяли. Влияние гипотиреоза на течение воспалительного процесса при пародонтите изучали на модели воспаления, вызванного острой травмой мягких тканей десен. Животным под тиопенталовым наркозом (30 мг/кг) с губной стороны к тканям пародонта нижнего резца подводили рабочую головку ультразвукового генератора - излучатель от ультразвукового скейлера ART (Великобритания), и осуществляли однократное направленное влияние колебаниями ультразвуковой частоты при следующих параметрах воздействия: частота колебаний 50 кГц, мощность излучения 1,2 Вт·см² при экспозиции воздействия 60 с. Операцию проводили на четырнадцатый день после первого введения мерказолила. Через 1 и 8 суток после операции крыс декапитировали под тиопенталовым наркозом (50 мг/кг). Группами сравнения служили животные с экс=периментальным гипотиреозом и крысы с острой механической травмой мягких тканей десен. Контролем служил материал от интактных животных.

Результаты. Воспаление у крыс с острой травмой десен на фоне гипотиреоза приводило к увеличению содержания активных нейтрофилов в периферической крови, снижению CD-4-лимфоцитов, нарушению соотношения основных субпопуляций лимфоцитов (CD-4 и CD-8), сопровождалось достоверным снижением иммунорегуляторного индекса, угнетением секреции IgG, IgM и IgA на системном уровне.

Выводы. У эутиреоидных крыс наблюдается нормальное течение воспалительного процесса с преобладанием роста Т-хелперов над уровнем цитотоксических Т-лимфоцитов и, соответственно, ростом иммунорегуляторного индекса. Обнаружена недостаточность клеточного звена иммунного ответа отражает усиление взаимного негативного воздействия воспалительного процесса в пародонте и системных нарушений иммунной защиты в 
Огляди літератури, оригінальні дослідження, погляд на проблему, ювілеї

условиях сопутствующего дефицита гормонов щитовидной железы. При моделировании острого пародонтита на фоне гипотиреоза отмечалось угнетение гуморального звена иммунной системы уже на первые сутки, которое характеризовалось достоверным снижением иммуноглобулинов всех классов.

КЛЮчЕВЫЕ СЛОВА: воспаление пародонта; гипотиреоз; неспецифические и специфические звенья иммунной защиты.

\section{FEATURES OF NON-SPECIFIC AND SPECIFIC LINKS OF IMMUNE PROTECTION IN RATS WITH ACUTE PERIODONTITIS WITH HYPOTHYRODISM}

\section{Horbachevsky Ternopil State Medical University}

@T. I. Dzetsiukh

SUMMARY. To study the effect of experimental hypothyroidism on the state of nonspecific and specific immune defense in rats with acute soft tissue injury of the gums, we determined the NBT test, indicators of the cellular component of the immune system (CD4, CD8), and studied the content of IgG, IgM and IgA in serum StatFax (USA).

The aim - to study the features of non-specific and specific parts of the immune defense in rats with acute periodontitis with hypothyroidism.

Material and Methods. Hypothyroidism in rats was caused by the administration of mercazolil at a dose of $25 \mathrm{mg} / \mathrm{kg}$ for 21 days. Control was carried out on the level of thyroxin, triiodothyronine and thyroid-stimulating hormone, as well as on the mass of animals and their physical activity. The comparison group included animals that were not used by Mercazolil. The effect of hypothyroidism on the course of the inflammatory process in periodontitis was studied on the model of inflammation caused by acute injury of the soft tissues of the gums. Under the thiopental anesthesia (30 mg/ $\mathrm{kg})$ on the labial side, the working head of the ultrasonic generator - radiator from the ART ultrasonic scaler (US) was brought to the periodontal tissues of the lower incisor, and a single directional influence of ultrasonic frequency oscillations was performed for $60 \mathrm{~s}$ with the following exposure parameters: the oscillation frequency is $50 \mathrm{kHz}$, the radiation power is $1.2 \mathrm{~W} \cdot \mathrm{cm}^{2}$ with an exposure exposure of $60 \mathrm{~s}$. The operation was performed on the fourteenth day after the first injection of mercazolil. After 1 and 8 days after surgery, rats were decapitated under thiopental anesthesia (50 mg/kg). The comparison groups were animals with experimental hypothyroidism and rats with acute mechanical injury of the soft tissues of the gums. Control served material from intact animals.

Results and Discussion. Inflammation in rats with acute gum injury on the background of hypothyroidism led to an increase in the content of active neutrophils in peripheral blood, a decrease in CD-4 lymphocytes, a violation of the ratio of the main lymphocyte subpopulations (CD-4 and CD-8), accompanied by a significant decrease in immunoregulatory index, inhibition of secretion IgG, IgM and IgA at the system level.

Conclusions. In euthyroid rats, the normal course of the inflammatory process is observed with a predominance of T-helper growth over cytotoxic T-lymphocytes and, accordingly, an increase in immunoregulatory index. A deficiency in the cellular level of the immune response was found to reflect the reinforcement of the mutual negative effects of the inflammatory process in the periodontium and systemic disorders of the immune defense in conditions of a concomitant thyroid hormone deficiency. When simulating acute periodontitis on the background of hypothyroidism, depression of the humoral component of the immune system was noted already on the first day, which was characterized by a significant decrease in immunoglobulins of all classes.

KEY WORDS: periodontal inflammation; hypothyroidism; non-specific and specific parts of the immune defense. 